The Journal of

Thoracic and

Cardiovascular

Surgery

\title{
Information for Readers
}

\section{Communication}

Communications regarding original articles and editorial management should be addressed to Andrew S. Wechsler, MD, Editor, Editorial Office, The Journal of Thoracic and Cardiovascular Surgery, Drexel University College of Medicine, 245 N 15th St, MS 496, Philadelphia, PA 19102; telephone: 215-762-1854; fax: 215-762-1858. Information for authors appears in each issue. Authors should consult these instructions before submitting manuscripts to this Journal.

Customer Service (orders, claims, online, change of address). Elsevier Periodicals Customer Service, 6277 Sea Harbor Drive, Orlando, FL $32887-$ 4800. Tel: (800) 654-2452 (U.S. and Canada); (407) 345-4000 (outside U.S. and Canada). Fax: (800) 225-6030 (U.S. and Canada); (407) 363-9661 (outside U.S. and Canada). E-mail: elspcs@elsevier.com

Address changes must be submitted four weeks in advance.

Yearly Subscription Rates. United States and possessions: Individual \$270; Institution \$532; Student/Resident \$135. All other countries (prices include airspeed delivery): Individual \$324; Institution \$587; Student/ Resident $\$ 162$. Single Issues $\$ 49$. To receive student/resident rate, orders must be accompanied by name of affiliated institution, date of term and the signature of program/residency coordinator on institution letterhead. Orders will be billed at the individual rate until proof of status is received Current prices are in effect for back volumes and back issues.

Further information on this journal is available from the Publisher or from this journal's website (http://www.elsevier.com/locate/jtcvs). Information on other Elsevier products is available through Elsevier's website (http:// www.elsevier.com).

Advertising information. Advertising orders and inquiries can be sent to: USA, Canada, and South America, Bill Scully, Cunningham Associates, 180 Old Tappan Rd, Old Tappan, NJ 07675; phone (201) 767-4170; fax (201) 767-8065. Classified advertising orders and inquiries can be sent to Traci Peppers, Elsevier Inc., 360 Park Avenue South, New York, NY 10010; phone (212) 633-3766. Europe and the rest of the world, Julie Toop; phone +44 (0) 1865 843016; fax +44 (0) 1865 843976; e-mail media@elsevier.com.

Author inquiries. For inquiries relating to the submission of articles (including electronic submission where available), please visit Elsevier's Author Gateway at http://authors.elsevier.com. The Author Gateway also provides the facility to track accepted articles and set up e-mail alerts to inform you of when an article's status has changed, as well as detailed artwork guidelines, copyright information, frequently asked questions, and more. Please see Information for Authors for individual journal. Contact details for questions arising after acceptance of an article, especially those relating to proofs, are provided after registration of an article for publication.

( $)$ The paper used in this publication meets the requirements of ANSI/ NISO Z39.48-1992 (Permanence of Paper).

Reprints. For queries about author offprints, e-mail authorsupport@ elsevier.com. To order 100 or more reprints for educational, commercial, or promotional use, contact the Commercial Reprints Department, Elsevier Inc., 360 Park Avenue South, New York, NY 10010-1710. Fax: (212) 462-1935; e-mail reprints@elsevier.com. Reprints of single articles avail- able online may be obtained by purchasing Pay-Per-View access for $\$ 30$ per article on the journal website, www.mosby.com/jtcvs.

Microform edition available from ProQuest Information and Learning, 300 N Zeeb Rd, Ann Arbor, MI 48106-1346.

(c) 2005 The American Association for Thoracic Surgery. All rights reserved.

This journal and the individual contributions contained in it are protected under copyright by The American Association for Thoracic Surgery, and the following terms and conditions apply to their use:

Photocopying. Single photocopies of single articles may be made for personal use as allowed by national copyright laws. Permission of the Publisher and payment of a fee is required for all other photocopying, including multiple or systematic copying, copying for advertising or promotional purposes, resale, and all forms of document delivery. Special rates are available for educational institutions that wish to make photocopies for non-profit educational classroom use. Permissions may be sought directly from Elsevier's Rights Department in Philadelphia, PA, USA: phone (+1) 215238 7869, fax (+1) 215238 2239, e-mail healthpermissions@elsevier.com. Requests may also be completed online via the Elsevier homepage (http://www.elsevier.com/locate/permissions). In the USA, users may clear permissions and make payments through the Copyright Clearance Center, Inc., 222 Rosewood Drive, Danvers, MA 01923, USA; phone: (+1) (978) 7508400, fax: (+1) (978) 7504744, and in the UK through the Copyright Licensing Agency Rapid Clearance Service (CLARCS), 90 Tottenham Court Road, London W1P OLP, UK; phone: (+44) 207631 5555; fax: (+44) 207631 5500. Other countries may have a local reprographic rights agency for payments.

Derivative Works. Subscribers may reproduce tables of contents or prepare lists of articles including abstracts for internal circulation within their institutions. Permission of the Publisher is required for resale or distribution outside the institution. Permission of the Publisher is required for all other derivative works, including compilations and translations.

Electronic Storage or Usage. Permission of the Publisher is required to store or use electronically any material contained in this journal, including any article or part of an article. Except as outlined above, no part of this publication may be reproduced, stored in a retrieval system or transmitted in any form or by any means, electronic, mechanical, photocopying, recording or otherwise, without prior written permission of the Publisher. Address permissions requests to: Elsevier Rights Department, at the fax and e-mail addresses noted above.

Notice. No responsibility is assumed by the Publisher or The American Association for Thoracic Surgery for any injury and/or damage to persons or property as a matter of products liability, negligence or otherwise, or from any use or operation of any methods, products, instructions or ideas contained in the material herein. Because of rapid advances in the medical sciences, in particular, independent verification of diagnoses and drug dosages should be made. Although all advertising material is expected to conform to ethical (medical) standards, inclusion in this publication does not constitute a guarantee or endorsement of the quality or value of such product or of the claims made of it by its manufacturer. 